\title{
Production and Quality Evaluation of Maize Chips (Kokoro) Produced from Maize and Whole Limabean Seed Flour Blends
}

\author{
Oluwafemi $\mathrm{GI}^{1^{*}}$, Seidu $\mathrm{KT}^{2}$ and Akinruli $\mathrm{BO}^{1}$ \\ ${ }^{1}$ Food Technology Department, Federal Polytechnic, Ado Ekiti, Nigeria \\ ${ }^{2}$ Hospitality and Tourism Management, Federal University Oye-Ekiti, Nigeria
}

*Corresponding author: Oluwafemi GI, Food Technology Department, Federal Polytechnic, Ado Ekiti, Nigeria, Tel: +2348035178766, Email: gbengaoluwafemi4u@gmail.com

Citation: Oluwafemi GI, Seidu KT, Akinruli BO (2018) Production and Quality Evaluation of Maize Chips (Kokoro) Produced from Maize and Whole Limabean Seed Flour Blends. J Adv Food Technol 1(1): 102. doi: 10.15744/2639-3328.1.102

Received Date: June 30, 2018 Accepted Date: July 13, 2018 Published Date: July 16, 2018

\begin{abstract}
This study investigated the proximate, mineral, and sensory properties of the composite flour and maize snack (kokoro) produced at different ratio of 100:0, 95:5, 90:10, 85:15, 80:20 respectively. The blends were reconstituted into a thick paste, manually moulded into kokoro stick and deep fried in hot vegetable oil. The kokoro and the flour blends were analysed for their proximate, mineral and sensory attributes. The result showed that there was a significant difference $(\mathrm{p}<0.05)$ in the proximate composition in all the blends. The results of the proximate composition of the flour blends ranged from 5.91 to $6.03 \%$ for moisture; 0.99 to $1.91 \%$ for ash; 8.00 to $12.07 \%$ for protein; 2.24 to $3.59 \%$ for fiber; 2.14 to $4.02 \%$ for fat; 73.23 to $80.79 \%$ for carbohydrate; while the result of the kokoro ranged from 7.02 to $8.48 \%$ for moisture; 1.91 to $3.41 \%$ for ash; 7.13 to $9.45 \%$ for protein; 6.83 to $11.04 \%$ for fiber; 7.13 to $7.83 \%$ for fat and 63.80 to $74.29 \%$ for carbohydrate. The mineral composition of flour blends ranged from 0.15 to $0.48 \%$ for phosphorus; 1.10 to $2.51 \%$ for calcium; 0.24 to $0.39 \%$ for magnesium; 0.15 to $0.30 \%$ for potassium; 0.04 to $0.12 \%$ for sodium and 0.76 to $71.80 \mathrm{mg} / \mathrm{kg}$ for iron. All minerals determined except iron all decreased as the substitution level with lima bean increases. The mineral composition of kokoro produced from the flour blends ranged from 0.13 to $0.18 \%$ for phosphorus; 1.00 to $1.38 \%$ for calcium; 0.10 to $0.29 \%$ for magnesium; 0.10 to $0.13 \%$ for potassium; 0.03 to $0.05 \%$ for sodium and 29.33 to $42.00 \mathrm{mg} / \mathrm{kg}$ for iron. All minerals determined in the kokoro, except sodium all decreased as the substitution level with lima bean increases. However, addition of lima bean at $5 \%$ increased the protein and fat content of both the kokoro and the flour, but the values were higher in the flour, compared to that of the maize snacks (kokoro). Kokoro of flour blends substituted with $15 \%$ lima bean was accepted in terms of sensory attributes.
\end{abstract}

Keywords: Proximate; Mineral; Sensory; Composite; Snack; Kokoro

\section{Introduction}

Snack foods have been described as sweet or savoury foods usually consumed to provide light sustenance in a quick and convenient format [1]. One peculiar characteristic of snack foods is that they are normally consumed between or as an alternative to main meals. The types of snack foods found in different localities are usually related to the food raw material availability and culture of the people. Some examples of snack foods include biscuits, meat pies and doughnuts from wheat flour; fried chips from potato, sweet potato or unripe plantain; fried foods from maize or cowpea paste; among others. In Nigeria, kokoro is a traditional maizebased snack popular in the south-western region made up of Ogun, Lagos, Oyo, Osun, Ekiti and Ondo states. Its commercial production is particularly dominant in Ogun state but the consumption is very common among the people in the region. The snack is an inexpensive commodity due to its relative low cost of production and is widely consumed by both the children and adults as a fried food product that is consumed between meals. The snack is usually produced in ring-like or fingerlike shape and people tend to enjoy it for its crunchy and tasty feelings. There are two distinct classes of kokoro, sour and non-sour types. The production process of the sour kokoro [2,3]. Snacks are becoming popular most especially in the urban cities due to the fact that most people now work far away from their homes. It is prepared and consumed in a multitude of ways which vary from region or from one ethnic group to the other. They are also used for the production of different convenient snacks foods which is eaten to prevent hunger before the main meals or just (as relish) for the fun of eating them [3]. Cereals are deficient in sulphur amino acids such as lysine, hence the need to compliment cereal (maize) with legumes such as groundnut, soybean, limabean which are better sources of the sulphur amino acids reported that a snack does not provide nutrients in adequate quantities needed by 
the body, which is due to their composition or due to the production process. Whatever might have been responsible for their poor nutritional content, it is necessary to ensure that food consumed as main meal or snacks contains required nutrients in adequate amount, this is important because most people now work outside their homes due to urbanization, and are becoming more dependent on snacks for the supply of part of their daily nutritional requirement [4,5]. It is therefore necessary to produce a highly acceptable snack with high nutritional quality that could be useful in nutrient deficiencies and combat malnutrition. Kokoro is a popular local snack in South Western Nigeria, made from maize flour. It is consumed during the day, usually alone or with roasted groundnut and washed down with soft drink or just water as a carrier. It is inexpensive compared with other snacks because of its relatively low cost of production, and is widely accepted among children and adult. As a product that is consumed on such wide scale, it would be important to enhance its nutritional value. Addition of legumes such as lima-bean, which is the area of concentration could be a way of increasing the nutritional value of the product [6]. Maize (Zea mays) is a member of the grass family Poaceae, it is a cereal grain which was first grown by people in ancient Central America. It is now the third most important cereal crop in the world. Maize is a leafy stalk whose kernels have seeds inside, it is an angiosperm (the seeds are enclosed inside a fruit or shell). It is used as a food staple by many people in Mexico, Central and South America and parts of Africa, most especially in Nigeria. The aim of this project work are to determine the proximate and the mineral composition of composite flour of maizelimabean flour blends, maize snack (kokoro) and the sensory evaluation of the kokoro.

\section{Materials and Methods}

\section{Materials}

Quality maize and lima bean used for this study were bought from Oja-Oba Ado Ekiti, Nigeria.

\section{Preparation of Maize and Lima Bean Flour}

The dry maize and lima bean were cleaned and sorted to remove stones, dirt, debris. The cleaned lima bean were weighed and dehulled manually. They were then dried at $60^{\circ} \mathrm{C}$ for $20 \mathrm{hr}$. The dried lima beans were dry milled to obtain the lima bean flour. The dry maize grains were winnowed to remove dust, dirt and foreign matter. They were conditioned to soften the hulls, the hulls were removed, oven dried and milled into powder using a milling machine.

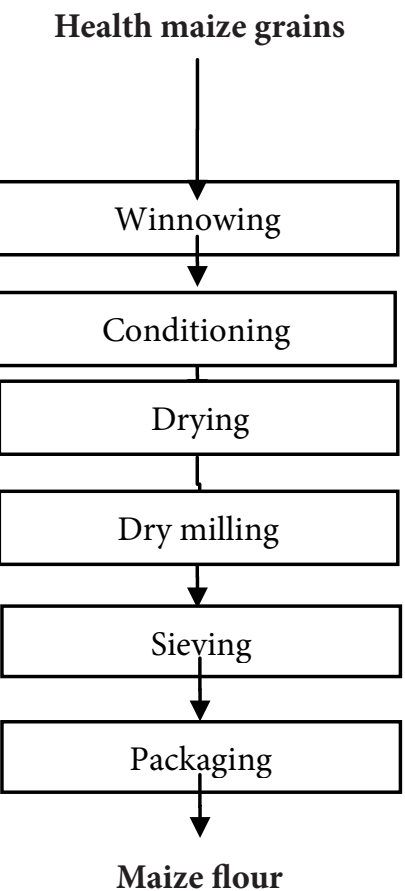

Figure 1: Flow chart for the production of maize flour 


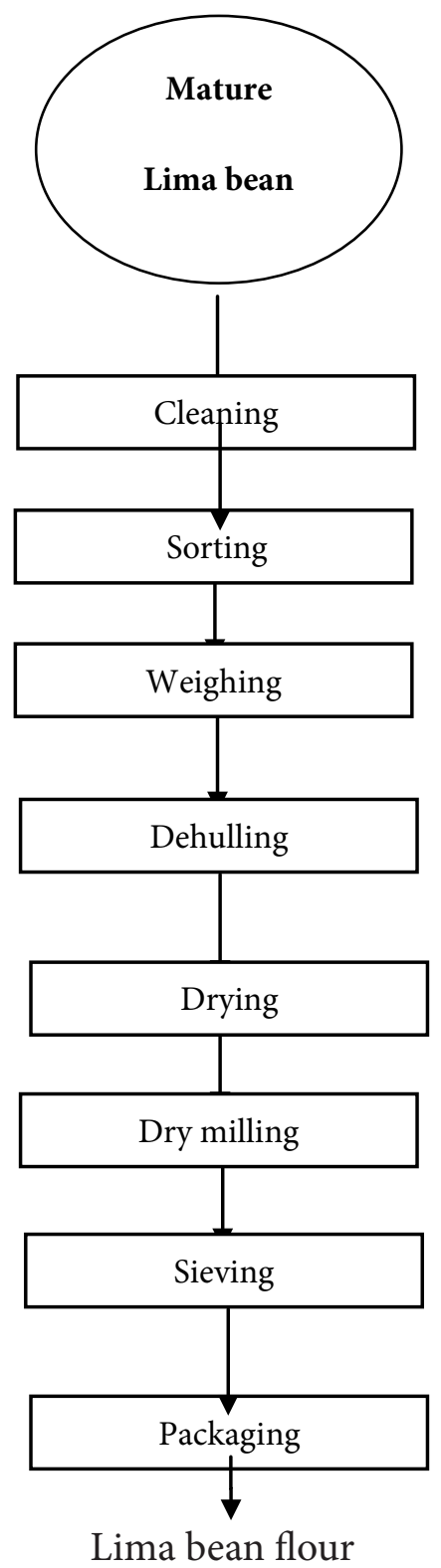

Figure 2: Flow chart for the production of lima bean flour

\section{Preparation of Maize Snacks}

Maize snack (kokoro) was produced as described by with a slight modification in the recipe used as onion and salt were used in place of sugar and salt [7]. The maize-lima beans were mixed thoroughly in various proportions as follows:
A: $100 \%$ maize flour
B: $95 \%$ maize flour $+5 \%$ Undefatted lima bean flour
C: $90 \%$ maize flour $+10 \%$ Undefatted lima bean flour.
D: $85 \%$ maize flour $+15 \%$ Undefatted lima bean flour.
E: $80 \%$ maize flour+20\% Undefatted lima bean flour.

A known weight of each blend was mixed and stirred in boiled water to make a paste and the remaining half was mixed with salt and onions and then added to the paste with continuous stirring for about 3 minutes to form homogenous dough. The dough was allowed to cool to a temperature of $40^{\circ} \mathrm{C}$ and kneaded by hand on a chopping board, cut into sizes and rolled into noodle shapes, then deep fried in hot vegetable oil at $170{ }^{\circ} \mathrm{C}$ for 5 minutes. The fried maize snacks were left to cool, drained and packaged in polythene. The flame intensity was constant throughout the deep frying of all the samples [8].

\section{Chemical Analysis}

Moisture, crude fibre, fat, protein, carbohydrate and ash contents of samples were determined according to [9]. Mineral elements of the samples were determined by the dry ashing method described by [10]. 
Mixture of maize and Lima bean flour

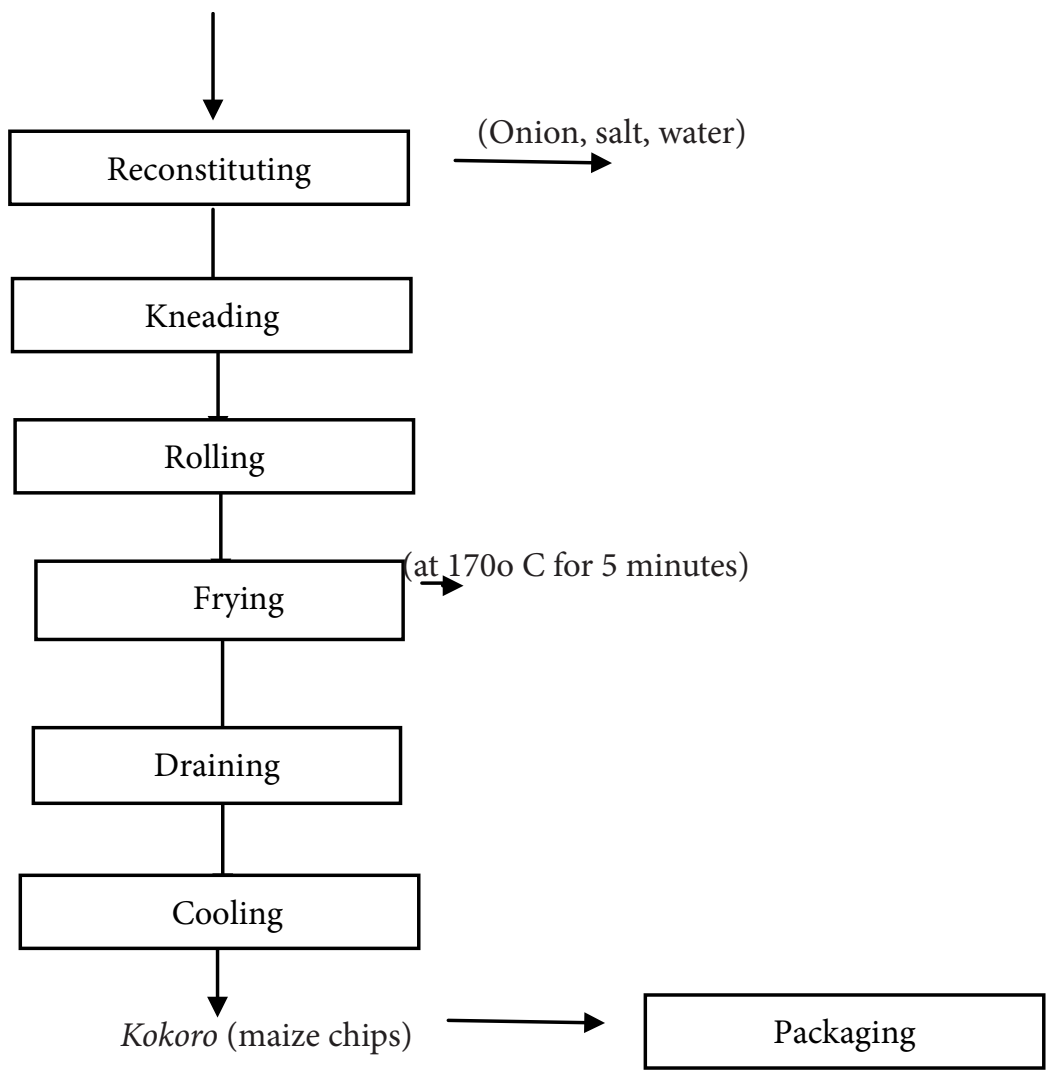

Figure 3: Flow chart for the production of kokoro

\section{Sensory Properties judging}

Maize snacks were determined using a twenty semi-trained panelist. Samples prepared from each blend were presented and coded white plastic plate, using a 9 point hedonic scale with a scale ranging of 1 to 9 with 1 representing the least score (dislike extremely) and 9 the highest score (like extremely). The order of presentation of samples was randomized. The panelists were instructed to evaluate the coded samples for crispiness, colour, taste, texture, flavour and overall acceptability [11].

\section{Statistical analysis}

All analysis was determined in triplicates and data were subjected to analysis of variance (ANOVA) using statistical package for social scientist (SPSS version 21) computer package. Mean were separated by New Duncans' Multiple Range Test, significance was taken at $\mathrm{p} \leq 0.05$. Error was reported as standard deviation from the mean.

\section{Results and Discussion}

\section{Proximate Composition of Kokoro Chips}

The result in Table 1 below shows the proximate composition of Kokoro chips (maize-lima bean blends). The moisture content of Kokoro ranged between 7.02-8.48\% with sample E (80: 20B) having the lowest value and sample A (100: 0B) having the highest value, the moisture content decreases with increase in lima bean composition and there was no significant difference between sample C (90: 10B) and sample D (85: 15B), the moisture content of the samples was low compared to values reported by [12]. Maize-Cowpea blends (10.45-11.05\%). The low moisture content is desirable since high moisture content may affect the storability and product quality [13]. It also indicates that the sample blends can be kept for a longer period if properly kept. The Fiber content also decreased with increase in the substitution with lima bean ranging between sample A (100: 0B) to E (80: 20B) with values 11.04-6.83\% which are higher compared to values reported by maize-soy flour blend snacks (1.21\%), fiber content may contribute to bulk and encourage bowel movement, prevent constipation and piles, reduce blood cholesterol and prevent cancer of the colon $[14,15]$. The Protein content of Kokoro ranged between 7.13-9.45\% with sample B (95: 5B) having the highest value (9.45\%) and sample E (80:20B) having the lowest value (7.13\%) compared with the values reported by Maize-Cowpea flour blends (15.2023.03\%) [16]. The Ash content ranged between 1.91-3.41\%, values which are higher compared to values reported by Apula snacks made from maize Bambara nut blend (1.66-2.86\%) [17]. The Carbohydrate and Fat content ranged between 69.97-74.29\% and 7.13-7.83\% respectively with sample A (100: 0B) having the highest value of Carbohydrate and B (95: 5B) having the lowest value, this may be due to the fact that maize naturally contains more amount of Carbohydrate than Lima- bean, and sample B (95:5B) having the highest value and sample E (80:20B) having the lowest value, although still within the range, increase in the A (95: 5B) Fat content may be due to the fact that little amount of Lima-bean (5\%) was added [18]. 


\begin{tabular}{|c|c|c|c|c|c|c|}
\hline Sample & Moisture (\%) & Ash (\%) & Protein (\%) & Crude fiber (\%) & Fat (\%) & Carbohydrate (\%) \\
\hline A & $8.48 \pm 0.16^{\mathrm{a}}$ & $3.41 \pm 0.04^{\mathrm{a}}$ & $7.15 \pm 0.12^{\mathrm{d}}$ & $11.04 \pm 0.10 \mathrm{a}$ & $7.22 \pm 0.10^{\mathrm{b}}$ & $74.29 \pm 0.72^{\mathrm{a}}$ \\
\hline B & $7.97 \pm 0.12^{b}$ & $2.99 \pm 0.05^{\mathrm{b}}$ & $9.45 \pm 0.25^{\mathrm{a}}$ & $7.97 \pm 0.12^{\mathrm{b}}$ & $7.83 \pm 0.06^{\mathrm{a}}$ & $63.80 \pm 0.59^{\mathrm{e}}$ \\
\hline $\mathrm{C}$ & $7.37 \pm 0.12^{c}$ & $2.64 \pm 0.17^{c}$ & $7.90 \pm 0.17^{\mathrm{b}}$ & $7.87 \pm 0.06^{\mathrm{b}}$ & $7.23 \pm 0.12^{\mathrm{b}}$ & $66.80 \pm 0.63^{\mathrm{d}}$ \\
\hline D & $7.23 \pm 0.06^{c}$ & $2.12 \pm 0.08^{\mathrm{d}}$ & $7.47 \pm 0.12^{c}$ & $7.47 \pm 0.06^{c}$ & $7.40 \pm 0.35^{\mathrm{b}}$ & $68.32 \pm 0.54^{c}$ \\
\hline E & $7.02 \pm 0.10^{\mathrm{d}}$ & $1.91 \pm 0.13^{\mathrm{e}}$ & $7.13 \pm 0.06^{\mathrm{d}}$ & $6.83 \pm 0.06^{\mathrm{d}}$ & $7.13 \pm 0.06^{b}$ & $69.97 \pm 0.20^{\mathrm{b}}$ \\
\hline
\end{tabular}

\section{Proximate Composition of Maize and Lima-Bean Flour Blends}

The moisture content of flour varied significantly with respect to the level of Lima-bean substitution, the Moisture content ranges from 5.91-6.37\% with sample MFL (95: 5A) having the highest value and MFL(80: 20A) having the lowest value, the values are lower compared to values reported by Maize-Soy flour blends which ranged between 9.25-12.19\% [19] (Table 2). The Ash content of the Flour decreased with increase in the substitution level of Lima-bean flour, the values ranged between $0.99-1.91 \%$ with sample $M F(100: 0 \mathrm{~A})$ having the highest value and $\operatorname{MFL}(80: 20 \mathrm{~A})$ having the lowest value, which could be due to the addition of lima-bean to the samples. The Protein content of flour (maize-lima bean blends) ranged between 8.00-12.07\% with sample MFL (95: 5A) having the highest value and MFL (100: 0A) having the lowest value, this could be due to the addition of lima-bean to the sample. Reported that protein can be supplied to food by supplementing cereals (maize) with legumes such as cowpea, limabean and soybean which are better sources of protein [4]. The Fiber content ranged between 2.24-3.59\% with sample MF (100:0A) having the highest value and MFL (80:20A) having the lowest value, this could be due to the increase in the lima-bean proportion. The Fat content ranged between 2.14-4.02\% with sample MF (100:0A) having the lowest value and sample MFL (95: 5A) having the highest value, this may be due to the fact that sample MF (100:0A) is not substituted with lima-bean flour, in view of this, it will be less susceptible to oxidative rancidity. The Carbohydrate content ranged between 73.23-80.79\% with sample MFL (95: 5A) having the lowest value and sample MF ((100:0A) having the highest value, this may be due to the fact that maize naturally is a rich source of carbohydrate than lima-bean [18]. The Moisture, Ash, Fiber and Fat content in kokoro (maize snack) was much higher than that of the composite flour (maize-lima bean blend), while the Protein and Carbohydrate content of the flour blends were significantly higher compared to that of kokoro. This may be due to the fact that the maize snacks had gone through the process of heating (frying at $170{ }^{\circ} \mathrm{C}$ for 5 minutes), and the higher Fat content could be due to the deep frying of the product.

\begin{tabular}{|c|c|c|c|c|c|c|}
\hline Sample & Moisture (\%) & Ash (\%) & Protein (\%) & Crude fiber (\%) & Fat (\%) & Carbohydrate (\%) \\
\hline MF100 & $6.30 \pm 0.06^{\mathrm{b}}$ & $1.91 \pm 0.01^{\mathrm{a}}$ & $8.00 \pm 1.41^{\mathrm{b}}$ & $3.59 \pm 0.07^{\mathrm{a}}$ & $2.14 \pm 0.14^{\mathrm{e}}$ & $80.79 \pm 0.56^{\mathrm{a}}$ \\
\hline MFL5 & $6.37 \pm 0.12^{\mathrm{a}}$ & $1.19 \pm 0.02^{\mathrm{b}}$ & $12.07 \pm 0.23^{\mathrm{b}}$ & $3.12 \pm 0.10^{\mathrm{b}}$ & $4.02 \pm 0.05^{\mathrm{a}}$ & $73.23 \pm 0.04^{\mathrm{d}}$ \\
\hline MFL10 & $6.24 \pm 0.08^{\mathrm{a}}$ & $1.06 \pm 0.03^{\mathrm{c}}$ & $11.05 \pm 0.26^{\mathrm{b}}$ & $2.58 \pm 0.13^{\mathrm{c}}$ & $3.51 \pm 0.13^{\mathrm{b}}$ & $75.56 \pm 0.16^{\mathrm{d}}$ \\
\hline MFL15 & $6.02 \pm 0.02^{\mathrm{b}}$ & $1.01 \pm 0.04^{\mathrm{cd}}$ & $9.63 \pm 0.29^{\mathrm{c}}$ & $2.38 \pm 0.03^{\mathrm{d}}$ & $3.17 \pm 0.08^{\mathrm{c}}$ & $77.80 \pm 0.36^{\mathrm{c}}$ \\
\hline MFL20 & $5.91 \pm 0.03^{\mathrm{b}}$ & $0.99 \pm 0.04^{\mathrm{d}}$ & $9.38 \pm 0.32^{\mathrm{c}}$ & $2.24 \pm 0.05^{\mathrm{d}}$ & $2.90 \pm 0.03^{\mathrm{d}}$ & $78.91 \pm 0.34^{\mathrm{b}}$ \\
\hline
\end{tabular}

Mean \pm standard deviations of triplicate determinations.

Means in the same column with the same superscript are not significantly different $(\mathrm{P}>0.05)$

MF100 $=100 \%$ maize flour, MF5B $=95 \%$ maize flour $+5 \%$ lima bean, MF10B $=90 \%$ maize flour $+10 \%$ lima bean,

MF15B $=85 \%$ maize flour $+15 \%$ lima bean, MF20B $=80 \%$ maize flour $+20 \%$ lima bean

Table 2: Proximate composition of maize and lima bean flour blends.

\section{Mineral Composition of Kokoro (maize-lima bean blends)}

Table 3 shows the Mineral Composition of Kokoro (maize-lima bean blends), there was significant difference $(\mathrm{p}<0.05)$ in the samples. Phosphorus, calcium, magnesium, potassium and iron decreased with increase in the substitution level of lima-bean. For sample C (90:10B) having the highest value of sodium and the least value was found in sample with $15 \%$ lima bean flour. 100\% maize flour had the highest value of Phosphorous, calcium, magnesium, potassium and Iron but was not significantly different from sample with 5\% Lima bean substitution level. However, least value for each of the element determined was observed in sample with $20 \%$ lima bean substitution level.

\begin{tabular}{|c|c|c|c|c|c|c|}
\hline Sample & Phosphorus & Calcium & Magnesium & Potassium & Sodium & Iron \\
\hline A & $0.18 \pm 0.01^{\mathrm{a}}$ & $3.30 \pm 0.01^{\mathrm{a}}$ & $0.29 \pm 0.01^{\mathrm{a}}$ & $0.13 \pm 0.01^{\mathrm{a}}$ & $0.04 \pm 0.01^{\mathrm{ab}}$ & $42.00 \pm 0.87^{\mathrm{a}}$ \\
\hline B & $0.18 \pm 0.00^{\mathrm{a}}$ & $1.31 \pm 0.09^{\mathrm{a}}$ & $0.18 \pm 0.01^{\mathrm{b}}$ & $0.13 \pm 0.01^{\mathrm{a}}$ & $0.04 \pm 0.00^{\mathrm{ab}}$ & $39.67 \pm 1.16^{\mathrm{b}}$ \\
\hline C & $0.15 \pm 0.01^{\mathrm{b}}$ & $1.12 \pm 0.06^{\mathrm{b}}$ & $0.16 \pm 0.01^{\mathrm{c}}$ & $0.11 \pm 0.00^{\mathrm{b}}$ & $0.05 \pm 0.01^{\mathrm{a}}$ & $37.3 \pm 1.16^{\mathrm{c}}$ \\
\hline D & $0.14 \pm 0.00^{\mathrm{c}}$ & $1.02 \pm 0.04^{\mathrm{c}}$ & $0.12 \pm 0.01^{\mathrm{d}}$ & $0.11 \pm 0.01 \mathrm{~b}^{\mathrm{c}}$ & $0.03 \pm 0.00^{\mathrm{c}}$ & $31.67 \pm 0.58^{\mathrm{d}}$ \\
\hline E & $0.13 \pm 0.00^{\mathrm{d}}$ & $1.00 \pm 0.01^{\mathrm{c}}$ & $0.10 \pm 0.01^{\mathrm{e}}$ & $0.10 \pm 0.00^{\mathrm{c}}$ & $0.04 \pm 0.01^{\mathrm{ab}}$ & $29.33 \pm 0.58^{\mathrm{e}}$ \\
\hline
\end{tabular}

Mean \pm standard deviations of triplicate determinations.

Means in the same column with the same superscript are not significantly different $(\mathrm{P}>0.05)$

Table 3: Mineral composition of kokoro 


\section{Mineral Composition of Maize and Lima-Bean Flour Blends}

Table 4 shows the mineral composition of maize and lima-bean flour blends.

\begin{tabular}{|c|c|c|c|c|c|c|}
\hline Sample & Phosphorus & Calcium & Magnesium & Potassium & Sodium & Iron \\
\hline MF100 & $0.48 \pm 0.02^{\mathrm{a}}$ & $2.51 \pm 0.04^{\mathrm{a}}$ & $0.39 \pm 0.02^{\mathrm{a}}$ & $0.30 \pm 0.17^{\mathrm{a}}$ & $0.12 \pm 0.01^{\mathrm{a}}$ & $0.76 \pm 0.01^{\mathrm{d}}$ \\
\hline MFL5 & $0.25 \pm 0.01^{\mathrm{b}}$ & $2.08 \pm 0.09^{\mathrm{b}}$ & $0.31 \pm 0.02^{\mathrm{b}}$ & $0.24 \pm 0.02^{\mathrm{b}}$ & $0.08 \pm 0.00^{\mathrm{b}}$ & $71.80 \pm 2.60^{\mathrm{a}}$ \\
\hline MFL10 & $0.20 \pm 0.01^{\mathrm{c}}$ & $1.61 \pm 0.04^{\mathrm{c}}$ & $0.30 \pm 0.00^{\mathrm{b}}$ & $0.21 \pm 0.01^{\mathrm{c}}$ & $0.06 \pm 0.00^{\mathrm{c}}$ & $53.88 \pm 4.91^{\mathrm{b}}$ \\
\hline MFL15 & $0.17 \pm 0.00^{\mathrm{d}}$ & $1.30 \pm 0.15^{\mathrm{d}}$ & $0.25 \pm 0.02^{\mathrm{c}}$ & $0.18 \pm 0.00^{\mathrm{d}}$ & $0.05 \pm 0.00^{\mathrm{d}}$ & $40.67 \pm 1.16^{\mathrm{c}}$ \\
\hline MFL20 & $0.15 \pm 0.01^{\mathrm{d}}$ & $1.10 \pm 0.05^{\mathrm{e}}$ & $0.24 \pm 0.01^{\mathrm{c}}$ & $0.15 \pm 0.01^{\mathrm{e}}$ & $0.04 \pm 0.00^{\mathrm{e}}$ & $36.00 \pm 1.73^{\mathrm{c}}$ \\
\hline
\end{tabular}

Mean \pm standard deviations of triplicate determinations.

Means in the same column with the same superscript are not significantly different $(\mathrm{P}>0.05)$

Table 4: Mineral composition of maize-lima bean flour blends

There was significant difference $(\mathrm{p}<0.05)$ in the samples. The phosphorus, calcium, magnesium, potassium and sodium content decreased with increase in substitution with lima bean. Sample MF (100: 0A) has the highest value for phosphorus, calcium, magnesium, potassium, sodium and sample MFL (80: 20A) had the lowest value, sample MFL (95: 5A) had the highest iron value. The $\mathrm{Na} / \mathrm{K}$ ratio in the body is important because it helps in controlling high blood pressure. $\mathrm{Na} / \mathrm{K}$ ratio values compare favorably with the recommended value of less than one [20]. The Ca/P ratio value was above one, therefore it was in line with what was reported by, that a food sample is considered good if the Ca/P ratio is above one but poor if less than 0.5 [21].

\section{Sensory Evaluation of Kokoro from Maize-Lima Bean Flour Blends}

From table 5, it was observed that sample D was rated best in term of colour with the rating value of 7.70 using hedonic scale, although was not significantly ( $p>0.05$ ) different from sample A but significantly higher than others. The high rating could be due to the attractive colour of lima bean flour that was used to replace $15 \%$ maize flour. Sample $\mathrm{C}$ was rated b best interm of crispiness and was significantly higher than other samples. Sample A, B, D and E were not significantly $(\mathrm{p}>0.05)$ different from each other. The tastes of the samples were not significantly different from one another except for sample D with the highest rating value of 6.10 . The flavour of each of the sample was significantly different from one another except for sample E which was no difference from sample A and C. The flavour could be as a result of the deep frying technique for the samples. Sample D was also rated best interm of texture although was not significantly $(\mathrm{p}>0.05)$ different from sample B but different from others. High texture rating could be as a result of the frying time for each sample. Sample D was rated best interm of overall acceptability.

\begin{tabular}{|c|c|c|c|c|c|c|}
\hline Sample & Colour & Crispiness & Taste & Flavor & Texture & Overall acceptability \\
\hline A & $4.30 \pm 2.06^{\mathrm{ab}}$ & $3.30 \pm 1.41^{\mathrm{c}}$ & $3.00 \pm 1.41^{\mathrm{b}}$ & $3.70 \pm 2.50^{\mathrm{ab}}$ & $3.90 \pm 2.33^{\mathrm{bc}}$ & $4.10 \pm 2.13^{\mathrm{bc}}$ \\
\hline B & $5.10 \pm 2.13^{\mathrm{b}}$ & $4.60 \pm 1.43^{\mathrm{bc}}$ & $4.30 \pm 2.06^{\mathrm{b}}$ & $5.20 \pm 2.20^{\mathrm{a}}$ & $5.60 \pm 1.78^{\mathrm{ab}}$ & $5.30 \pm 1.89^{\mathrm{ab}}$ \\
\hline C & $5.50 \pm 1.27^{\mathrm{b}}$ & $4.80 \pm 1.40^{\mathrm{a}}$ & $4.20 \pm 2.20^{\mathrm{b}}$ & $4.00 \pm 1.76^{\mathrm{ab}}$ & $4.60 \pm 1.65^{\mathrm{bc}}$ & $5.00 \pm 1.56^{\mathrm{ab}}$ \\
\hline D & $7.70 \pm 1.16^{\mathrm{a}}$ & $6.00 \pm 1.83^{\mathrm{c}}$ & $6.10 \pm 1.85^{\mathrm{a}}$ & $5.60 \pm 2.37^{\mathrm{a}}$ & $7.00 \pm 1.76^{\mathrm{a}}$ & $6.70 \pm 1.77^{\mathrm{a}}$ \\
\hline E & $3.10 \pm 0.88^{\mathrm{c}}$ & $3.40 \pm 0.52^{\mathrm{c}}$ & $3.00 \pm 1.41^{\mathrm{b}}$ & $3.10 \pm 1.73^{\mathrm{b}}$ & $3.10 \pm 1.73^{\mathrm{c}}$ & $3.60 \pm 1.17^{\mathrm{c}}$ \\
Mean \pm standard deviations of triplicate determinations. \\
Teans in the same column with the same superscript are not significantly different $(\mathrm{P}>0.05)$ \\
Table 5ensory evaluation of maize snacks (Kokoro)
\end{tabular}

\section{Conclusion}

The substitution with lima bean had actually improved the nutritional quality of the snacks, in terms of protein at the substitution level of 5\% lima bean flour. Although, as the substitution level of lima bean increases, the ash content decreases which is an indication that the kokoro from the composite flour will lack some minerals. Therefore, kokoro from maize-lima bean flour blend will serve as a better nutritional snack; perhaps keep longer due to the low moisture content and helps to re-address the problem of protein energy malnutrition among infants in developing countries. From the result so far, as regards the sensory score and the proximate composition, I hereby recommend that kokoro produced from maize and lima bean flour blend of $15 \%$ substitution level should be encouraged and a better developmental procedure could be adopted to improve the flavor in further research.

\section{Acknowledgement}

This work was supported by the Department of Food Technology, Federal Polytechnic Ado Ekiti, Nigeria.

\section{References}

1. Bolade MK (2018) Physical and organoleptic characteristics of non-sour 'kokoro' (a Nigerian maize-based snack) as influenced by flour particle size differential. LWT - Food Science and Technology 87: 287-92.

2. Oranusi S, Dahunsi SO (2015) Preliminary study on hazards and critical control points of kokoro, a Nigerian indigenous fermented maize snack. Springerplus 4: 253. 
3. Fasasi OS, Omotayo A (2013) Physiochemical properties, vitamins, antioxidant activities and amino acid composition of ginger spiced maize snacks "kokoro" enrich hed with soya flour. Department of Food Science and Technology, Federal University of Technology 4: 73-7.

4. Okaka JC (2005) Basic processing of garri cereals and legumes in handling, storage and processing of plants food. OCJ Academic publishers, Enugu Nigeria $30-60$.

5. Onuh JO, Abulsalam KO (2009) Production and evaluation of physic-chemical properties of maize-bambara groundnut (apula). Nigeria Food Journal 27: 83-92.

6. Rose RAC, Chavez-Jauregul EM, Mariam ES, Pinto JA (2003) Acceptability of snacks produced by extrusion of Amaranth and blend of chicken pea and bovine lung. International Journal of food science technology 38: 795-8.

7. Uzo-peters PJ, Arisa NU, Lawerence CO, Osondu NS, Adelaja A (2008) Effect of partially defatted soyabeans or groundnut cake flours on proximate and sensory characteristics of kokoro. African Journal of Food Science 2: 98-101.

8. Olapade AA, Oke OV, Okafor JNC (2002b) Consumer acceptability of kokoro prepared from maize, supplemented with Bambara nut, proceedings of 26th Annual Conference and general meeting of Nigerian Institute of Food Science and Technology.

9. AOAC Official Methods (2000) Association of Official Analytical Chemists. (17th Edn) Washington, USA.

10. Kumar D, Jhariya NA (2013) Nutritional, medicinal and economical importance of corn: A mini review. Res. J. Pharmaceutical Sci 2: 7-8.

11. Ghosh D, Konishi T (2007) Anthocyanins and anthocyaninrich extracts: Role in diabetes and eye function. Asia Pac J Clin Nutr 16: 200-8.

12. Adeyemo TB, Abegunde TA, Bolaji OT (2014) Quality Evaluation of maize chips (kokoro) fortified with cowpea flour. Nigerian Food Journal 32: 94-104.

13. Abdel-Aal EM, Young JC, Rabalski I (2006) Anthocyanin composition in black acceptability of kokoro prepared from maize supplemented with Bambara nut, proceeding of 26th annual conference and general meeting of Nigerian Institute of Food Science and Technology, 2002.

14. Sade FO, Aderonke AO (2013) Physicochemical properties, vitamins, antioxidant active and amino acid composition of ginger spiced maize snack kokoro enriched with soyflour a Nigerian based snack). Department of Food science and Technology 4: 73-7.

15. Higgins JA (2004) Resistant starch: Metabolic effects and potential health benefits. J AOAC Int 87: 761-8.

16. Darrah LL, Mc-Cullen MD, Zuba MS (2003) Breeding, genetics and seed corn production, chapter two. In: PJ White, L.A Johnson, eds. Corn-chemistry and technology. (2nd edn) American Association of cereal chemist, Inc St.paul, Minesota, USA 35-68.

17. Ames-Jiang YZ, Wang T (2005) Phytosterols in cereal by-products. Journal of the American Oil Chemists' Society 82: 439-44.

18. Kopsell DA, Armel GR, Mueller TC, Sams, CC, Deyton DE, et al. (2009) Increase in nutritionally important sweet corn kernel carotenoids following mesotrione and atrazine applications. J Agric Food Chem 57: 6362-8.

19. Fakorede MAB (2001) Revolutionizing Nigerian Agriculture with golden seed. Inaugural lecture series Obafemi Awolowo University press limited Ile-Ife Nigeria 82: 456-510.

20. Olapade AA, Oke OV, Olaokun OO, Okafor JNC (2006) Consumer of kokoro prepared from maize, supplemented with Bambara nut, proceedings of 26th Annual Conference and general meeting of Nigerian Institute of Food Science and Technology.

21. Lopez-Martinez LX, Oliart-Ros, RM, Valerio-Alfaro G, Lee CH, Parkin KL, et al. (2009) Antioxidant activity of Phenolic compounds and Anthocyanins content of eighteen strains of Mexican maize. LWT Food Science and Technology 42: 1187-92.

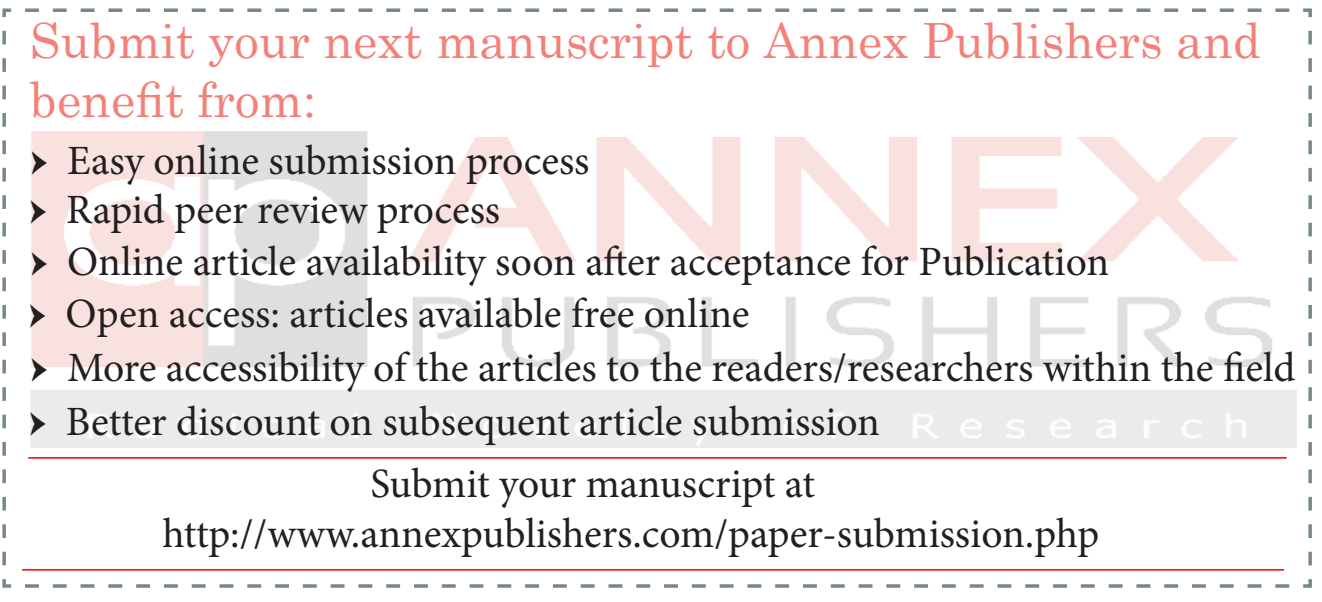

